Ritrýnd grein birt 31. desember 2020

\title{
„Ég er alltaf glaðari og ég er miklu sjálfstæðari en ég var“ Starfshættir í grunnskóla sem styður sjálfræði nemenda
}

\author{
Ingibjörg V. Kaldalóns \\ Abstract $\quad$ Um höfund $\quad$ About the author $\quad$ Heimildir
}

Viðfangsefni pessarar greinar er að varpa ljósi á starfshætti í grunnskóla sem hefur sjálfsákvörðunarkenningar að faglegu leiðarljósi. Samkvæmt peim er sjálfræði nemenda grundvöllur sjálfstjórnar, áhuga og velfarnaðar í námi og pví mikilvægt að styðja sjálfræði nemenda. Rannsóknir í íslenskum grunnskólum á stuðningi við sjálfræði eru fáar, en rannsókn frá 2015 sýnir að hann er víða lítill. Hér er sagt frá tilviksrannsókn í 8.-10. bekk par sem gerð var vettvangsathugun sjö skóladaga vorið 2018 og fimm daga vorið 2019, tekin prjú rýnihópaviðtöl við fjóra nemendur (samtals 12) og átta einstaklingsviðtöl við fimm starfsmenn. Einnig var unnið úr gögnum úr sjálfsmati skólans. Markmið með rannsókninni var að kanna hvort og hvernig áherslur og starfshættir í grunnskólanum NÚ styðja sjálfræði nemenda og kanna upplifun og reynslu nemenda af peim. Rannsókninni er ætlað að varpa ljósi á starfshætti sem styðja sjálfræði nemenda og gildi peirra fyrir nemendur. Niðurstöður sýndu að víða mátti sjá stuðning við sjálfræði nemenda í skólastarfinu, til dæmis með möguleikum nemenda á vali og hvetjandi samskiptum. Formgerð sem er ætlað að styðja sjálfræði nemenda er í stöðugri próun. Til dæmis var hannað hvatakerfi sem umbunar nemendum með auknu frelsi fyrir verkefnaskil og góða framkomu. Vendinám, leiðsagnarmat og upplýsingatækni gegndu jafnframt lykilhlutverki í að halda utan um nám og verkefnaskil hvers nemanda. Pá var áhersla á sjálfsskoðun nemenda og persónulegan vöxt fléttuð inn í allt skólastarfið, til dæmis með núvitundarkennslu, markpjálfasamtölum og hugarfarspjálfun. Reynsla nemenda af skólastarfinu var góð. Peir töldu að skólavistin efldi sjálfstæði peirra, peim fannst gaman í skólanum og peir fundu tilgang með námi sínu við skólann. Margt má læra af starfsháttum skóla par sem stöðugt er verið að próa námsskipulag sem styður vöxt og sjálfræði nemenda, auk pess sem jafnframt er stuðlað að ánægju og sjálfsábyrgð nemenda.

Efnisorð: Stuðningur við sjálfræði, sjálfsákvörðunarkenningar, starfshættir í skólastarfi, reynsla nemenda

\section{Inngangur}

Viðfangsefni pessarar greinar er að varpa ljósi á starfshætti grunnskóla sem hefur pað að markmiði að styðja sjálfraði (e. autonomy support) nemenda og kanna reynslu nemenda af peim. Greint er frá tilviksrannsókn sem fram fór í grunnskólanum NÚ. NÚ er sjálfstætt rekinn grunnskóli fyrir nemendur í 8.-10. bekk. Skólinn var stofnaður árið 2016 og hefur pví lokið sínu fjórða starfsári. Um 60 nemendur stunda nám við skólann. Námið er sérstaklega hugsað fyrir nemendur sem stunda ípróttir, pó engar kröfur séu gerðar um árangur í ípróttum. Auk pess að styðja sjálfræði nemenda er yfirlýst markmið skólans að styðja áhugasvið peirra, heilsu og velfarnað (framsynmenntun.is). Stuðningur við sjálfraði vísar til pess hvaða aðsteður eru skapaðar i skólastarfi (formgerð, andrúmsloft, 
svigrúm) til að styðja sjálfreð̇i nemenda, en nánar verður fjallað um pað hér á eftir. Skólinn vakti athygli rannsakanda sem einn af fáum í heiminum sem hefur svokallaðar sjálfsákvörðunarkenningar (SÁK, e. self-determination theories, SDT) að faglegu leiðarljósi. Pessar kenningar og rannsóknir á grundvelli peirra hafa pótt mikilvægt framlag til pess að skýra velfarnað, áhugahvöt og sjálfstjórn, sem eru lykilpættir í námi (Admiraal, Nieuwenhuis, Kooij, Dijkstra og Cloosterman, 2019; Roth og Deci, 2009, bls. 78-79).

Samkvæmt sjálfsákvörðunarkenningum er sjálfræði ein af sálrænum grundvallarpörfum mannsins, p.e. að upplifa pá tilfinningu að athafnir séu sjálfsprottnar, pær séu í samræmi við eigin áhuga, gildi og vilja. Sjálfræði er ekki einungis pörf, heldur einnig meðfædd tilhneiging til að stjórna eigin athöfnum og eigin lífi. Dví merkir sjálfræði nemenda hér að athafnir peirra séu i samremi við eigin vilja og sannfaringu. Aðrar sálfræðilegar grunnparfir eru annars vegar að upplifa hafni (e. competence) og að fá tækifæri til að sýna pá hæfni í tilteknu félagslegu samhengi. Hins vegar er pörf fyrir félagstengsl (e. relatedness), p.e. að upplifa gagnkvæma umhyggju og pað að tilheyra jafnt einstaklingum sem samfélagi. Sé pessum premur sálfræðilegu pörfum mætt skapast grunnur að farsæld og nemendur eru fremur drifnir áfram af innri áhugahvöt. Enn fremur lýsir kenningin hvernig innri sjálfstjórn getur lærst ef grunnpörfunum er mætt (Reeve, Deci og Ryan, 2004; Reeve, Ryan, Deci og Jang, 2008; Ryan, Curren og Deci, 2013; Ryan og Deci, 2017, 2020; Ryan, Huta og Deci, 2008; Sheldon og Ryan, 2011). Rannsóknir á hvernig grunnpörfunum er mætt í skólastarfi hafa flestar beinst að sjálfræðispörfinni. Pær sýna jafnframt að kennarar sem styðja sjálfræði nemenda mæta iðulega einnig pörf peirra fyrir hæfni og félagstengsl, enda felur stuðningur við sjálfræði meðal annars í sér að hlusta eftir pörfum og sjónarmiðum nemenda, bæði hvað varðar hæfni og umhyggju (Ryan og Deci, 2017, 2020).

Fjöldi rannsókna undir hatti sjálfsákvörðunarkenninga sýnir fram á mikilvægi pess að styðja sjálfræði nemenda í skólastarfi. Til dæmis má nefna samantekt Reeve (2009) á 44 empírískum rannsóknum birtum í alpjóðlegum tímaritum og safngreiningu (e. meta-analyses) Su og Reeve (2011). Niðurstöður allra pessara rannsókna eru af sama meiði. Pær sýna fram á ávinning nemenda af aðstæðum sem styðja sjálfræði í skólastarfi fram yfir aðstæður par sem pað er ekki stutt. Pannig er sjálfræði nemenda tengt áhugahvöt, sjálfstjórn og skuldbindingu nemenda til náms, námsskilningi, námsgengi, sjálfstrausti, sköpunargleði og vellíðan, svo eitthvað sé nefnt (sjá nánar í Reeve, 2009; Su og Reeve, 2011). Nýlegri rannsóknir hafa einnig staðfest pessar niðurstöður (til dæmis Jang, Reeve og Halusic, 2016; Núnez og León, 2019; Patall og Zambrano, 2019; Yu, Li, Want og Zhang, 2016).

Hér á landi hefur nokkuð verið skrifað um petta út frá tengdum hugtökum. Par má til dæmis nefna rannsóknir á fræðasviði sem hefur verið kallað raddir nemenda (e. student voice). Par má vísa til rannsókna Jóhönnu Einarsdóttur, sem beinast að áhrifum ungra barna í skólastarfi og lýðræðislegum starfsháttum (2008), sem og svokallaðrar Starfsháttarannsóknar par sem pátttaka nemenda í ákvörðunum var í brennidepli (Rúnar Sigpórsson, Anna-Lind Pétursdóttir og Póra Björk Jónsdóttir, 2014). Einnig ber að nefna rannsóknir Steinunnar Gestsdóttur sem hefur notað hugtakið sjálfráða sjálfstjórn (e. intentional regulation) í rannsóknum sínum sem snúast um tengsl sjálfstjórnar við farsæld og æskilegan proska grunnskólanemenda (Steinunn Gestsdóttir og Freyja Birgisdóttir, 2010; Steinunn Gestsdóttir og Lerner, 2007). Pá hafa tengsl sjálfstjórnar og virkrar pátttöku í skólastarfi verið könnuð (Kristján Ketill Stefánsson, 2017). Í doktorsrannsókn Guðrúnar Öldu Harðardóttur er fjallað um tækifæri barna til áhrifa út frá hugtakinu valdefling (Guðrún Alda Harðardóttir og Baldvin Kristjánsson, 2012) . Lítið hefur samt birst af rannsóknum hér á landi sem fjalla um sjálfræði og skólastarf eins og hér verður gert. Pó ber að nefna nýlega grein Hafdísar Ingvarsdóttur (2018) sem fjallaði um hvort og pá hvernig kennarar í framhaldsskólum stuðluðu að sjálfræði með starfsháttum sínum.

Рað er sem sé lítið um fyrirliggjandi rannsóknir á fræðasviði sjálfsákvörðunarkenninga sem beinast að stuðningi við sjálfræði nemenda í íslenskum grunnskólum. Í rannsókn á starfsháttum í 14 grunnskólum frá 2015 kom fram að stuðningur við sjálfræði nemenda var víðast hvar ekki mikill (Ingibjörg V. Kaldalóns, 2015). Í rannsókn sem fjallaði um hvað hindraði kennara í að styðja sjálfræði 
nemenda kom jafnframt fram að kennarasamfélagið skorti sýn eða hugmyndir um hvernig haga bæri starfsháttum pannig að petta yrði unnt (Ingibjörg V. Kaldalóns, 2017). Dví er mikilvægt fyrir íslenskt skólastarf að skilningur verði aukinn á starfsháttum sem styðja sjálfræði nemenda og einnig að reynsla nemenda af slíkum starfsháttum verði könnuð, eins og gert er í pessari grein.

\section{Starfshættir sem styðja sjálfræði nemenda}

Fræðafólk á sviði sjálfsákvörðunarkenninga hefur nálgast eflingu sjálfræðis út frá hugtakinu stuðningur við sjálfræði (e. autonomy support). Pó rannsóknum á hvernig styðja megi sjálfræði hafi ekki fylgt útfærðar kennsluleiðbeiningar hafa rannsakendur á pessu sviði engu að síður bent á nokkra pætti sem greina kennsluhætti sem styðja sjálfræði nemenda (og innri áhugahvöt og sjálfstjórn) frá peim sem gera pað ekki.

\section{Svigrúm til ákvarðana}

Kennarar styðja sjálfræði nemenda með áherslu á val og með pví að gera nemendum kleift að taka pátt í ákvörðunum um nám sitt. Rannsakendur hafa pó áréttað að pað purfi að vera um raunverulegt val að ræða (til dæmis um námsefni eða hvernig verkefni er unnið) eigi pað að hafa tilætluð áhrif á upplifun nemenda á námi sínu. Pannig hafi pað ekki endilega áhrif á upplifun nemenda á námi að leyfa peim að velja milli kosta sem peim pykja allir óáhugaverðir (Assor og Kaplan, 2001; Assor, Kaplan og Roth, 2002). Petta merkir einnig að mikilvægt er að skapa nemendum aðstæður par sem peir geta lært á eigin hraða, og á pann máta sem peim finnst henta sér best, og umhverfi sem hvetur pá til frumkvæðis og til pess að deila hugmyndum sínum. Í pessu samhengi er bent á gildi prautalausna og leitaraðferða (e. problem solving, inquiry) sem kennsluaðferða par sem áhersla er lögð á námsferlið og framlag nemenda fremur en útkomu eða rétt svör (Admiraal o.fl., 2019; Jang o.fl., 2016; Reeve og Assor, 2011, bls. 126-127). Sumir fræðimenn hafa fjallað um slíkar áherslur með tilvísun í hugtakið stuðningur við vitsmunalegt sjálfreði (e. cognitive autonomy support), en pá eru nemendur hvattir til að bera ábyrgð á námi sínu, m.a. með leitaraðferðum og með hvatningu til að finna ólíkar leiðir til úrlausna (Admiraal o.fl., 2019; Stefanou, Perencevich, DiCintio og Turner, 2004). Stefanou og félagar (2004) telja jafnframt stuðning við vitsmunalegt sjálfræði nemenda vera mikilvægari en svigrúm nemenda til að hafa áhrif á skipulag námsins (e. organizational autonomy support) eða val peirra á leiðum til að skila af sér verkefnum (e. procedural autonomy support) ef stuðla á að helgun í námi.

\section{Svigrúm til sjálfsígrundunar}

Eigi nemendur að taka sjálfráðar ákvarðanir í skólastarfi pá purfa peir að pekkja eigin vilja og sannfæringu sem peir sỉðan byggja ákvarðanir sínar á. Pví parf skóli sem styður sjálfræði nemenda meðal annars að skapa aðstæður par sem nemendur geta rannsakað og öðlast reynslu á sviðum sem peir kunna að hafa áhuga á. Pannig parf að ýta undir að peir geti próað hæfni gegnum sitt áhugasvið, sem styður síðan próun innri (sjálfsráðs) áhuga (Reeve, 2006; Reeve og Assor, 2011). Til að kveikja áhuga og skuldbindingu nemenda gagnvart námi purfa kennarar jafnframt að setja sig í spor nemenda, pekkja (sjálfsett innri) markmið peirra, áhugasvið, parfir og styrkleika (e. inner resources) og tengja petta allt við skólastarfið (Reeve, 2006; Reeve og Assor, 2011).

Í pessu skyni hefur í rannsóknum verið horft til samtalsaðferða milli kennara og nemenda sem stuðla að aukinni sjálfspekkingu nemenda og virka sem innri leiðarvísir eða áttaviti peirra (e. formation of authentic inner compass). P.e.a.s. að skapaðar séu aðstæður í skólastarfinu par sem nemendur eru hvattir til ígrundandi samræðna um markmið sín, afstöðu og gildismat og peim pannig hjálpað að komast að hvað hafi persónulega pýðingu fyrir pá og hvað peim pyki eftirsóknarvert. Pegar kennarar hvetja til slíkra umræðna er sýnt að nemendur verða sjálfráðir í pátttöku sinni í skólastarfi. Detta verður einnig til pess að nemendur fá pjálfun í að taka ákvarðanir sem eru í samræmi við eigin gildi 
og eigið sjálf (Reeve og Assor, 2011). Kaplan og Assor (2012) hafa próað samtöl milli kennara og nemenda til að styðja sjálfræði (e. autonomy supportive I-thou dialogue). Kennarar voru pjálfaðir í samræðum við bekkjarheildir eða litla hópa í 7. bekk sem höfðu pað markmið að efla sjálfræði nemenda. Í samtölunum var rætt um: a) pýđingu námsins og námsgreina í ljósi áhugamála nemenda og framtíðarmarkmiða peirra, b) valmöguleika peirra í námi og hvata til sjálfstæðrar hugsunar, og einnig var í viðtölunum lögð áhersla á að c) nemendur mættu gagnrýna námið og skólastarfið. Niðurstöður sýndu að nemendur sem tóku pátt í slíkum samtölum við kennara sína voru jákvæðari gagnvart kennurum og pýðingu námsins og að sama skapi minnkuðu hegðunarvandkvæði. Pannig hafa sálfræðingarnir Johnmarshall Reeve og Avi Assor (2011), sem eru mest áberandi í rannsóknum á stuðningi við sjálfræði, lagt áherslu á mikilvægi sjálfsígrundunar og sjálfsskoðunar nemenda. Sköpuð sé formgerð og andrúmsloft par sem nemendur ná að móta sinn innri áttavita í samræmi við markmið, gildi og áhugamál (Reeve og Assor, 2011). Í nýlegri hollenskri rannsókn lögðu kennarar að sama skapi áherslu á að efla sjálfsskilning nemenda (e. self-insight) með pað að markmiði að styðja sjálfræði peirra (Admiraal o.fl., 2019).

\section{Hvetjandi samskipti}

Rannsóknir hafa sýnt hvernig jákvæð og upplýsandi samskipti eru mikilvægur páttur pess að styðja sjálfræði. Til dæmis sé mikilvægt að leggja áherslu á virka hlustun og að haga sætaskipan pannig að nemendur séu gerðir að miðpunkti í samtölum fremur en að peir eigi að horfa og hlusta óvirkir - pannig sé í gegnum allt starfið sýnt með skýrum hætti að sjónarmið nemenda séu virt (Reeve, 2006; Reeve o.fl., 2004). Í nýlegri rannsókn Hafdísar Ingvarsdóttur (2018) var einmitt fjallað um virðingu gagnvart nemendum sem mikilvægan pátt í að hlúa að sjálfræði peirra, ásamt að kennarar treysti nemendum til að bera ábyrgð á námi sínu eins og áđur var fjallað um. Pá sýna rannsóknir að pegar setja eigi reglur eða takmarkanir pá purfi að huga að hvernig pær séu settar fram. Petta sé spurning um hvort barnið upplifi námsumhverfið sem upplýsandi og hvetjandi eða stýrandi. Fái barnið upplýsandi og jákvæð fyrirmæli hefur pað ekki neikvæð áhrif á innri áhugahvöt (til dæmis sköpunarkraft og vinnugleði) en fái pað fyrirmæli sem einkennast af stjórnræði (e. control) pá hefur slíkt neikvæð áhrif á innri áhugahvöt og upplifun af sjálfræði (Koestner, Ryan, Bernieri og Holt, 1984). Í pessu samhengi skiptir einnig máli að orðaval og raddblær sé hvetjandi og uppbyggilegur pannig að nemendur upplifi ekki prýsting eða pvingun í námsumhverfi sínu (Koestner o.fl., 1984).

Jafn mikilvægt er að pað sem kennarar segja sé upplýsandi. Pegar nemendur eru beðnir að vinna tiltekin verkefni parf að útskýra nákvæmlega til hvers sé ætlast og hvers vegna. Pá sé lögð áhersla á að gefa nemendum leiðbeinandi endurgjöf um hvernig peim gangi með tiltekin verkefni. Pannig sé t.a.m. ekki nóg að segja nemanda að honum gangi vel, heldur purfi að gera fulla grein fyrir hvað honum gangi vel með og hvers vegna. Sýnt pykir að slíkar áherslur vinni gegn áhugaleysi og slæmri hegðun og frammistöðu (Reeve, 2006; Reeve o.fl., 2004; Reeve og Halusic, 2009).

Pá hafa rannsóknir sýnt fram á mikilvægi pess að kennarar viðurkenni neikvæðar tilfinningar nemenda, til dæmis ef peim finnst námið erfitt eða leiðinlegt. Skólar setja reglur og gera tilteknar kröfur um nám og hegðun nemenda en einnig parf að bera virðingu fyrir sjónarmiðum nemenda í peim efnum. Рað geta t.a.m. verið gildar ástæður fyrir pví að nemendur bregðist við tilteknum kröfum á neikvæðan hátt. Rétt er að vinna með pessar neikvæðu tilfinningar, virða viðbrögð nemenda, ræða pau og læra af peim, í stað pess að hunsa pau. Slíkar umræður geta meðal annars fengið nemendur til að skilja pýðingu pess að tilteknar kröfur séu gerðar (Assor og Kaplan, 2001; Reeve, 2006; Reeve og Halusic, 2009).

\section{Merkingarbært nám og reglur}

Sýnt hefur verið fram á mikilvægi pess að kennarar geri nemendum grein fyrir pýðingu (e. relevance) peirra verkefna sem peir taka sér fyrir hendur, en sá páttur tengist sterklega jákvæðni nemenda gagnvart námi (Assor o.fl., 2002). Með pýðingu er átt við að kennari útskýri hvers vegna nemendur 
eigi að læra vissa hluti og hvernig pað geti komið að notum fyrir pá. Pegar nemendur purfa að vinna verkefni sem peir hafa ekki áhuga á verður enn fremur meiri pörf á að kennarinn útskýri pýðingu verkefnisins en pegar peir vinna eftir innri áhugahvöt. Pannig er nemendum hjálpað að skilja hvers vegna peir ættu taka (sjálfráðar) ákvarðanir um að verja tíma og orku í tiltekin verkefni sem peim pykja ekki áhugaverð, jafnvel leiðinleg (Reeve, 2006). Að sama skapi er mikilvægt, pegar nemendur eru beðnir að sýna tiltekna hegðun, að slíkir rammar séu settir fram á grundvelli gilda og hafi pví pýðingu fyrir pá, peim sé gert kleift að átta sig á pýðingu rammanna eða reglnanna og afleiðingum pess að pær séu brotnar (Reeve, 2006), og taka sjálfráðar ákvarðanir um athafnir sínar á grundvelli pess.

\section{Samspil sjálfræðis og formgerðar}

Í SÁK er gerður skýr greinarmunur á stýringu (e. control) og formgerð (e. structure) eða námsskipulagi (Ryan og Deci, 2020). Rannsóknir hafa sýnt að nemendur helga sig best námi sínu (e. engagement) í námsumhverfi sem styður sjálfræði en er jafnframt vel skipulagt (sjá t.d. Jang, Reeve og Deci, 2010). Með skipulagi er átt við að nemendum sé gerð góð grein fyrir peim kröfum sem gerðar eru til peirra. Pannig sé til dæmis ljóst hvaða verkefni peir skuli taka sér fyrir hendur, hversu mikið efni peir skuli komast yfir og hvaða markmiðum peir vinni að. Enn fremur sé hlustað eftir rödd nemenda, peim veitt visst valfrelsi og leyft að hafa frumkvæði innan peirrar formgerðar sem peim er sköpuð (Reeve, 2006; Reeve o.fl., 2004; Reeve og Halusic, 2009). Einnig hefur verið sýnt fram á samverkandi áhrif skipulags og stuðnings við sjálfræði á sjálfstjórn nemenda í námi. Pannig hefur formgerð sterk jákvæð tengsl við sjálfstjórn í námi pegar leiðbeiningar, rammar og kröfur eru sett pannig fram að nemendum finni fyrir stuðningi við sjálfræði (Sierens, Vansteenkiste, Goossens, Soenens og Dochy, 2009). Gert sé ljóst til hvers sé ætlast af peim en peir hafi samt sem áður frelsi til að hafa áhrif á nám sitt. Petta er pví spurning um framsetningu ramma og reglna og áherslu á frelsi innan rammanna.

Fyrrgreindar rannsóknir sýna að stuðningur við sjálfræði kemur fram í að nemendum er skapað rými eða frelsi til að upplifa sjálfræði í athöfnum sínum. Рað er gert með pví að skapa formgerð sem veitir nemendum svigrúm til sjálfsígrundunar, nemendum er treyst til að taka ákvarðanir um nám og skólastarf, peim er sýnd virðing og peir hvattir til að tjá eigin hugmyndir, skoðanir og tilfinningar. Einnig útskýra kennarar tilgang námsins. Par er lykilatriði að hægt er að efla sjálfræðið ef aðstæður eru skapaðar til pess í skólastarfi. Pó rannsóknir hafi bent á nokkra pætti sem greina kennsluhætti sem styðja sjálfræði nemenda frá peim sem gera pað ekki, pá er par ekki að finna tillögur um hvernig megi útfæra pær niðurstöður á vettvangi. Hér gefst tækifæri til að skoða pað. Markmið með rannsókninni er að kanna hvort og hvernig áherslur og starfshættir í NÚ styðja sjálfræði nemenda og heyra nemendur lýsa með eigin orðum reynslu sinni og upplifun af slíku starfi. Engar rannsóknir hafa verið gerðar á starfi skóla sem hefur pað að yfirlýstu markmiði að styðja sjálfræði nemenda í anda sjálfsákvörðunarkenninga, og er pví um nýlundu að ræða. Rannsókninni er pannig ætlað að varpa ljósi á starfshætti sem styðja sjálfræði nemenda og gildi peirra fyrir nemendur. Rannsóknarspurningarnar sem leitað er svara við eru tvær: 1) Hvernig birtist stuðningur við sjálfraði (i anda sjálfsákvördunarkenninga) i starfsháttum og áherslum NÚ? og 2) Hver er upplifun og reynsla nemenda af peim áherslum og starfsháttum? Í niðurstöðukafla verður leitað svara við pessum spurningum í tveimur meginköflum sem jafnframt byggjast á ólíkum gögnum sem nánar er greint frá í næsta kafla. Til að forðast endurtekningar verður umræðu fléttað saman við framsetningu á niðurstöðum.

\section{Rannsóknin}

Rannsóknin er tilviksrannsókn í grunnskólanum NÚ. Skólinn var valinn vegna peirrar yfirlýstu stefnu hans að leggja sérstaka áherslu á að styðja sjálfræði nemenda, eins og áður hefur verið greint frá. Um er að ræða prenns konar gögn; vettvangsathuganir, opin einstaklingsviðtöl við starfsfólk og rýnihópaviðtöl við nemendur skólans. Gagnaöflun fór fram á tveimur tímabilum; í apríl 2018 og aftur í maí 2019. 
Í apríl 2018 dvaldi rannsakandi á vettvangi í sjö skóladaga og fylgdist með starfsháttum. Pá voru einnig tekin tvö einstaklingsviðtöl við skólastjóra (70 mínútur hvort) og prjá starfsmenn skólans (30-40 mínútur hvert). Skólastjóri hafði milligöngu um að biðja kennara um pátttöku í viðtalsrannsókninni. Í maí 2019 fóru aftur fram vettvangsathuganir og rannsakandi dvaldi pá fjóra skóladaga á vettvangi til að fylgjast með starfinu. Í framhaldi var aftur tekið einstaklingsviðtal við skólastjóra (30 mínútur) og tvo kennara skólans (30-90 mín). Viðtölin voru hálfopin og stuðst var við samtalsramma. Pau fóru ýmist fram á skrifstofu skólans eða á kaffihúsum í nágrenni við skólann, eftir pví sem aðstæður leyfðu. Með vettvangsathugunum var unnt að fá tilfinningu fyrir skólabrag og samskiptum (andrúmslofti) og hvernig námsskipulagið var í framkvæmd. Í einstaklingsviðtölunum fengust svo útskýringar á pví sem fram fór, auk pess sem hægt var að heyra lýsingar starfsfólks á áherslum og starfsháttum sem tengdust stuðningi peirra við sjálfræði nemenda.

Í maí 2019 voru einnig tekin prjú rýnihópaviðtöl við nemendur skólans. Eitt viðtal var tekið við nemendur í hverjum árgangi par sem rætt var við tvær stelpur og tvo stráka í senn, samtals 12 nemendur (30-45 mínútur hvert viðtal). Viðtölin voru hálfopin og stuðst var við samtalsramma. Nemendur voru fyrirfram beðnir að bjóða sig fram, og skólastjóri sendi bréf til foreldra sem purftu að sampykkja skriflega pátttöku barnsins í viðtali. Rýnihópaviðtölin reyndust vel til að heyra hvernig nemendur ræddu um skólastarfið, með eigin orðum, og draga pannig fram mikilvægan lærdóm um peirra upplifun.

Til viðbótar við framangreind megingögn rannsóknarinnar fékk rannsakandi aðgang að gögnum úr innra mati skólans, svo sem Skólapúlsinum og öðrum könnunum sem skólinn hafði lagt fyrir nemendur sína. Skólapúlsinn nær til 80-90\% allra nemenda í 6.-10. bekk (Skólapúlsinn, 2018). Samkvæmt forsvarsmönnum Skólapúlsins eru niðurstöður settar fram með peim hætti að niðurstöður tiltekinna matspátta eru bornar saman við svör allra peirra nemenda sem tóku pátt í könnuninni. Hvað varðar túlkun á mun á milli skóla pá eru niðurstöður settar fram sem svokallaðar staðalníur (e. stanines). Peir benda á pá viðmiðunarreglu að munur upp á $0,5^{*}$ sé ekki mikill munur, munur upp á $1,0^{*}$ teljist töluverður munur en munur upp á $1,5^{*}$ teljist mikill. Stjörnumerktar niðurstöður merkir jafnframt að um marktækan mun sé að ræða. Út frá pessum fyrirliggjandi (megindlegu) gögnum var unnt að fá staðfestingu á pví sem eigindlegu gögnin sýndu um upplifun nemenda af skólastarfinu.

Greiningin var tvípætt eftir rannsóknarspurningunum tveimur. Viðtöl við starfsfólk og vettvangsathuganir voru greind eftir páttum sem komið hafa fram í fyrri rannsóknum á stuðningi við sjálfræði. Par voru meginpemun tvípætt; Svigrúm fyrir val og ákvarðanir nemenda (námsskipulag) og Sjálfsefling og hvetjandi samskipti. Í nemendaviðtölunum var hins vegar lögð áhersla á að greina orðfæri peirra og hver reynsla peirra væri af skólastarfinu með aðleiðslu. Lichtman (2013) lýsir slíku greiningarferli pannig að meðfram endurteknum yfirlestri gagna eru pau lykluð (e. coding), lyklar samræmdir og flokkaðir (e. categorize) og loks leitast við, með frekari greiningu gagnanna, að próa pemu (e. concepts) sem endurspegla meginniðurstöður. Pannig komu fram prjú meginpemu úr nemendagögnum; meira sjálfstaði, gaman i skólanum, nám sem hefur tilgang. Til staðfestingar á upplifun nemendanna voru einnig notaðar vettvangsathuganir, gögn úr Skólapúlsinum og ánægjukannanir meðal nemenda.

\section{Niðurstöður og umræður}

Niðurstöður eru settar fram í tveimur meginköflum. Annars vegar er greint frá námsskipulagi og megináherslum í starfi NÚ út frá pemunum Svigrúm fyrir val og ákvarðanir nemenda og Sjálfsskoðun og hvetjandi samskipti, en eins og áður hefur komið fram pá sýna fyrri rannsóknir að petta eru pættir sem styðja sjálfræði nemenda. Par er að mestu leyti stuðst við vettvangsathuganir og viðtöl við starfsfólk en einnig vísað til reynslu nemenda pegar hún getur varpað ljósi á starfshættina. Hins vegar er sjónum beint að upplifun og reynslu nemenda af pví að stunda nám við skólann út frá rýnihópaviðtölum við pá, sjálfsmatsgögnum og vettvangsathugunum. 


\section{Námsskipulag og megináherslur í starfi NÚ}

Í megindráttum snýst námsskipulagið í NÚ um að námsárinu er skipt í 10 námslotur par sem hver lota er prjár vikur. Í hverri priggja vikna lotu eru teknar fyrir prjár námsgreinar eða pemaverkefni (stundum pvert á námsgreinar) og hverri lotu lýkur með verkefnaskilum og leiðsagnarmati. Innlögn og formleg fræðsla fer jafnframt að mestu leyti fram á netinu, en hver nemandi fær sína tölvu við inngöngu í NÚ par sem hann getur nálgast nánast öll námsgögn. Vendinám og upplýsingatækni gegna pannig lykilhlutverki í náminu. Námsskipulagið hefur pó verið í stöðugri próun síðan skólinn hóf starfsemi.

\section{Svigrúm fyrir val og ákvarðanir nemenda}

Í vettvangsathugunum mátti sjá að stærsti hluti hins daglega skólastarfs var skilgreindur sem almennur vinnutími par sem nemendur fengu svigrúm til að ákveða hvaða verkefni voru unnin á hverjum tíma, út frá námsáætlun lotunnar. Að mati skólastjórans er pað jafnframt vendinámið, par sem innlögn kennara er fyrirfram aðgengileg á netinu, sem gerir nemendum mögulegt að sinna náminu á sínum hraða. Nemendur fylgdust pví með innlögn í skilgreindum vinnutíma og/eða heima í tengslum við verkefni lotunnar. Umfang og fjöldi verkefna var að einhverju leyti einstaklingsmiðað og pannig leitast við að námskröfur væru hæfilegar. „Allir nemendur eiga að skila tilteknum verkefnum, en sumir nemendur gera meira," útskýrði skólastjóri. Hlutverk kennara í kennslustundum var að aðstoða nemendur í pví sem peir tóku sér fyrir hendur. Pannig studdu kennarar hvern nemanda á peim stað par sem hann var staddur. Peir hjálpuðu nemendum við „að finna út úr hlutunum“ eins og pað var orðað. Einnig mátti sjá í vettvangsathugunum að kennarar notuðu iðulega spurningar pegar peir voru beðnir um aðstoð við að leysa verkefni. Pannig spurðu peir gjarnan „hvernig mundir pú útskýra pað?"“ eða „hvað stendur parna?“ og hvöttu pannig til umræðu um mögulegar leiðir og lausnir. Einn kennarinn orðaði petta svona:

Mér finnst svo mikilvægt að pau læri að tileinka sér ákveðin vinnubrögð. Leita að upplýsingum, meta pær og gagnrýna. Við erum að reyna að undirbúa pau og kenna peim pað sem pau purfa að tileinka sér seinna meir ... Pau purfa að læra að pú ert ekki mataður. Pau purfa tækifæri til að vinna saman og vinna sjálfstætt.

Pessar áherslur í skólastarfinu eru í anda pess sem Stefanou og félagar (2004) hafa skrifað um út frá hugtakinu stuðningur við vitsmunalegt sjálfreði (e. cognitive autonomy support). Með slíkum stuðningi eru nemendur hvattir til að eigna sér námið enn frekar, til dæmis með pví að hvetja pá til að finna ólíkar leiðir til úrlausna, færa rök fyrir máli sínu og að peir meti vinnu sína út frá viðmiðum sem peir hafa sjálfir lagt til.

Möguleikar nemenda á vali komu mikið við sögu í skólastarfinu. Fyrst ber að nefna að nemendur kusu að sækja nám í pessum skóla og höfðu undirgengist inntökuviðtöl par sem peir purftu meðal annars að útskýra áhuga sinn á pví að hefja nám hjá NƯ. Pá er lögð áhersla á að námið sé áhugadrifið par sem námsefni og verkefni eru iðulega tengd heilsu og ípróttum. Pannig var áhugasviðum til að mynda mætt í námsgreinum á borð við ípróttavísindi og náttúrufræði. Einnig má nefna vikulegar „snillistundir" sem eru í sumum lotum par sem nemendur velja sér verkefni eftir áhugasviði og velja skilaform verkefna, p.e.a.s. hvort pað er í formi ritgerðar, kynningar eða myndbandsupptöku, svo dæmi sé tekið. „Pá mega pau grúska og outputið má vera hvernig sem er,“ sagði einn kennarinn. Í pemaverkefnum mátti að sama skapi sjá hvar val nemenda kom við sögu. Peir áttu til dæmis að stofna fyrirtæki og ákváðu sjálfir hvers eðlis fyrirtækið skyldi vera, skiptu sjálfir með sér verkum og völdu skilaform líkt og í áhugasviðsverkefnum. Í verk- og listgreinum geta nemendur árlega valið úr 10 mögulegum listgreinum, auk greina eins og heimilisfræði og tónmennt sem allir nemendur fara í. Pá má nefna pátttöku nemenda í námsmati en hjá skólastjóra kom fram að „nemendur stýra foreldraviðtölum par sem pau kynna eigin markmið og námsstöðu og sýna verkefni sem pau völdu að sýna foreldrum“. 
Pessir starfshættir eru áhugaverðir í ljósi fyrri rannsókna á íslensku skólastarfi sem sýna að nemendur hafa óvíða svigrúm til að hafa áhrif á nám sitt. Til dæmis sýndu rannsóknir Gerðar G. Óskarsdóttur (2012) og Rúnars Sigpórssonar (2012) að flestir nemendur væru með sama námsefni og að peir hefðu lítið val um viðfangsefni, námsaðferðir eða skil. Á unglingastigi væri valið einkum fólgið í valgreinum. Rannsókn á starfsháttum í íslenskum grunnskólum frá árunum 2014-2015 sýndi að sama skapi að pátttaka nemenda í ákvörðunum væri takmörkuð (Rúnar Sigpórsson o.fl., 2014). Í sömu starfsháttarannsókn kom einnig fram að víða ættu nemendur að vera „á sama stað“ í námi og að námsefni samkvæmt námskrá væri í reynd talið mikilvægara en áhugasvið nemenda (Ingibjörg V. Kaldalóns, 2017).

Pannig var próað tiltekið námsskipulag í NÚ par sem nemendur fengu svigrúm til að taka ákvarðanir um nám sitt, lögð var áhersla á val og áhugadrifið nám, að nemendur settu sér markmið í náminu og gerðu verkáætlanir. Petta er í samræmi við niðurstöður Reeves og Assors (2011) en rannsóknir peirra sýna að með stuðningi við sjálfræði séu nemendum skapaðar aðstæður par sem peir geta lært á sínum hraða, og á pann máta sem peim finnst henta sér best. Peim sé skapað umhverfi sem hvetur til frumkvæðis og peir hvattir til að deila hugmyndum sínum. Einnig benda peir á að gera purfi nemendum kleift að taka pátt í ákvörðunum um nám sitt, til dæmis um innihald náms og námsmarkmiða og um námsmat (Reeve og Assor, 2011, bls. 123). Deir hafa einnig bent á mikilvægi pess að næra áhuga og lærdómshvöt með námi við hæfi hvers og eins. Lykilatriðið er sú áhersla að nemendur séu gerðir samábyrgir í öllu námsferlinu par sem pað auki sjálfræði peirra, sjálfsaga, sjálfstjórn og atbeina í námi (sjá til dæmis Bandura, 2008; Cleary og Zimmerman, 2004; Glasser, 1988).

Pó hér sé tilteknu námsfyrirkomulagi lýst, pá lagði skólastjóri áherslu á að starfshættir væru í stöðugri próun. Рað væri hins vegar ævarandi verkefni að próa námsskipulag par sem finna mætti jafnvægi milli pess frelsis sem hver nemandi hefði í námi sínu og peirra ramma og reglna sem honum væru settar. Skólastjóri sagðist óhræddur við að láta reyna á nýjar leiðir:

Við erum stöðugt að prófa okkur áfram. Fyrst var mjög lítið af prófum og mikill sveigjanleiki. Pá fengu pau priggja vikna pakka, hvað lægi fyrir í hverju fagi og purftu að skipuleggja sig sjálf ... Áttu að gera sér eigin verkáætlun. En pau réðu ekki við petta. Pau tóku námið ekki alvarlega. Næsta önn var mun stífari með tíðum verkefnaskilum og prófum til einkunna. Pá fannst nemendum pað ansi stíft. Í framhaldinu fórum við einhverja millileið og svo erum við að próa nýtt hvatakerfi sem heldur utan um petta.

Hvatakerfið sem hér er vísað til er kerfi sem umbunar nemendum með auknu frelsi og var próað í samstarfi við nemendur. Nemendur kölluðu petta fyrirkomulag „beltakerfið“ með tilvísun í beltin sem veitt eru í karate. Allir nemendur byrja „í hvíta beltinu“. Раð pýðir að nemendur vinna alltaf verkefnin sín í tilteknum stofum, kennarar hafa eftirlit með tölvunotkun og veita nemendum aðhald í verkefnavinnunni. Nemendur geta svo unnið sér inn meira frelsi með pví að skila verkefnum á tilsettum tíma og með góðri framkomu við samnemendur og kennara. Til að fá svarta beltið eru, auk verkefnaskila og framkomu, tiltekin hæfniviðmið í preki og vélritun sem nemendur purfa að ná. Umbunin felur í sér að nemendur bera aukna ábyrgð á námi sínu, lítið eftirlit er með tölvunotkun og peir læra hvernig og hvar sem peir vilja (í húsnæði skólans). Einnig eru framhaldsskólaáfangar í boði fyrir nemendur með svarta beltið. Í viðtölunum mátti heyra að kennarar jafnt sem nemendur voru spenntir fyrir pessu nýja kerfi. Meginmarkmið með hvatakerfinu er að koma til móts við ólíka pörf nemenda fyrir aðhald og auka frelsi peirra sem geta borið ábyrgð á sínu námi. Áhugavert verður að kanna reynslu nemenda af hvatakerfinu pví rannsóknir sýna mikilvægi pess að leiðbeiningar, rammar og kröfur séu settar pannig fram að nemendur upplifi að pær styðji sjálfræði, eins og áður var vikið að (Reeve, 2006; Reeve og Assor, 2011; Reeve o.fl., 2004; Reeve og Halusic, 2009; Sierens o.fl., 2009). Рað pýðir að námsskipulagið parf að vera skýrt en einnig sé hlustað eftir röddum nemenda, peim veitt ákveðið valfrelsi og peir hafi frumkvæði innan peirrar formgerðar sem peim er sköpuð. Pað er pví ljóst að jafnvel pegar skapa á svigrúm og frelsi nemenda til að hafa áhrif á nám sitt krefst pað skýrrar formgerðar. Î rannsókn á stuðningi við sjálfræði nemenda í 14 grunnskólum á Íslandi 
kom einmitt fram að pað tæki tíma að hanna og próa formgerð og skipulag sem veitir svigrúm fyrir val og ákvarðanir nemenda. Einnig kom fram að bæði nemendur og kennarar pyrftu tíma til að læra á pað (Ingibjörg V. Kaldalóns, 2015). Í ljósi pessa er áhugavert að sjá hvernig námsskipulag og formgerð hefur verið próuð hjá NÚ.

\section{Sjálfsskoðun nemenda og hvetjandi samskipti}

Í vettvangsathugunum mátti sjá að sjálfsefling nemenda og sjálfsskoðun er undirliggjandi páttur í öllu starfinu hjá NÚ. Með orðum skólastjórans: „Petta er í DNA-inu hjá okkur ... Við fáum pau til að vinna ólíka persónulega sigra. Sumir námslega. Sumir í framsögn. Aðrir í samskiptum. Mannkostamenntun í gegnum allt og pau eru mikið í sjálfsskoðun." Til upprifjunar hafa Reeve og Assor (2011) einmitt bent á sjálfsskoðun nemenda sem einn grundvallarpátt pess að styðja sjálfræði peirra, p.e.a.s. að peim séu skapaðar aðstæður til að móta sinni innri áttavita í samræmi við markmið, gildi og áhugamál. Hver skóladagur byrjar á svokallaðri núveru í 30 mínútur par sem markvisst er stuðlað að sjálfsskoðun og sjálfseflingu nemenda. Í pessum daglegu núverustundum er ýmist farið í gegnum núvitundaræfingar, slökun, jóga eða hugleiðslu með nemendum. Einnig fá peir tækifæri til ígrunda viðhorf sín og pau markmið sem unnið er með í pessum stundum. Sama má segja um markpjálfasamtölin, en nemendum er boðið upp á tvö til fjögur einstaklingssamtöl við markpjálfa á hverju námsári. Í samtölunum „vinna nemendur með gildin sín og átta sig á styrkleikum sínum“, auk pess sem peir fá stuðning til að vinna að markmiðum sínum, eins og peir lýstu í viðtölunum. Pessar áherslur mátti líka glögglega sjá á veggspjöldum sem prýddu veggi skólans. Til dæmis mátti sjá myndir af ípróttafólki og smellnum tilvitnunum um úthald og seiglu, svo sem: „To give anything less than your best is to sacrifice the gift“ og "It's not whether you get knocked down. It's whether you get up." Áherslur í skólastarfinu héngu innrammaðar uppi á vegg. Par stóð „Að læra að pekkja sjálfan sig“, „Að læra að vinna með öðrum“ og „Að læra að læra“. Pessar áherslur endurspegluðust einnig í fagsýn kennaranna. Einn peirra lýsti sinni fagsýn svona:

Ég vil að pau séu eins sátt og pau geta verið. Hafi eins mikla trú á sér og mögulegt er. Pau eru ekki fær í öllu en pau hafi færni til að takast á við ólík verkefni. Pau séu í sátt við sig sjálf og allt sem pau eru. Bæði styrkleika og veikleika ... pað kemur allt inn á petta. Að styrkja pau í sér.

Forsenda pess að hægt sé að hlúa að persónulegum vexti nemenda og styðja pá í sjálfsskoðun er að skólinn sé „öruggt umhverfi“, eins og kennarar orðuðu pað, pannig að nemendur pori að gera mistök og „láta á sig reyna“. Pjálfun í vaxtarhugarfari er pannig samofin öllu skólastarfinu par sem lögð er áhersla á að mistök séu til pess að læra af. Einn kennarinn orðaði pað svona: „Við tölum um að klúðra með stæl. Bara thumbs up og ekki fela mistökin“. Í vettvangsathugunum mátti jafnframt sjá hvernig unnið var að pví að skapa petta örugga námsumhverfi og jákvæðan skólabrag með uppbyggilegu orðfæri og hlýlegu viðmóti. Pannig mátti sjá kennara gefa nemendum „high-five“ eða „klesst‘ann“ pegar peir náðu að ljúka verkefnum, og skólastjórann taka á móti nemendum að morgni dags með pví að segja „gaman að sjá ykkur og velkomin í pennan frábæra dag“. Einnig mátti sjá hvernig nemendahópurinn safnaðist iðulega allur saman og samskipti virtust afslöppuð, enda taldi bæði starfsfólk og nemendur að smæð skólans skapaði einingu meðal nemendanna. Á hverju hausti er farið með námshópinn í priggja daga ferð sem er hugsuð sem „samhristingur“ fyrir hópinn. Par er „verið að byggja upp hópinn allan tímann" hafði einn kennarinn á orði. Einnig kom fram að nemendur væru beinlínis pjálfaðir í teymisvinnu og pannig hlúð að félagsfærni peirra. Pannig lagði skólastjóri áherslu á að nemendum væri ekki gert að finna út úr pví sjálfir hvernig ætti að vinna í hópi, heldur fengju peir kennslu og pjálfun í pví. Nemendur nefndu að sama skapi pýðingu haustferðanna og teymisvinnunnar við að byggja upp traust í nemendahópnum.

Rannsóknir á starfsháttum í íslenskum grunnskólum sýna að einungis fjórðungur starfsfólks telur skólann sinna pví hlutverki vel að efla persónulegan proska og sjálfsmynd nemenda sinna (Ingibjörg V. Kaldalóns, 2015). Í sömu rannsókn töldu hins vegar $80 \%$ kennara að leggja ætti mikla áherslu á pessa pætti í skólastarfi. Pannig telja langflestir kennarar petta vera mikilvægt hlutverk, en einungis 
fjórðungur telur pví vel sinnt. Af pessu má ætla að margir kennarar telji sig ekki vita hvernig peim beri að sinna pví hlutverki að efla persónulegan proska og sjálfsmynd nemenda. Í ljósi pess er áhugavert að líta til starfshátta hjá NÚ sem leitast við að sampætta pessar áherslur í gegnum allt skólastarfið. Í starfsháttum NÚ má jafnframt sjá hvernig grunnstef nýrrar menntastefnu Reykjavíkurborgar, um heilbrigði, sjálfseflingu og félagsfærni, birtist í skólastarfi. Stefnan er í anda barnasáttmála Sameinuðu bjóðanna og Aðalnámskrár grunnskóla (Mennta- og menningarmálaráðuneyti, 2011) en par segir að styrkja skuli andlega og líkamlega getu barna sem og hæfileika og persónuleika peirra (Reykjavíkurborg, Skóla- og frístundasvið, 2018).

\section{Upplifun og reynsla nemenda}

Eftir að hafa öðlast skilning á námsskipulagi og megináherslum í skólastarfi hjá NÚ var áhugavert að kynnast sjónarhorni nemenda og reynslu peirra af námi við skólann. Sem fyrr sagði fundust prjú meginpemu sem komu ítrekað fram og lýstu reynslu peirra. Рað voru lýsingar peirra á að hafa öðlast meira sjálfstæði, ánægja með skólastarfið og loks að peir fyndu tilgang með námi sínu við skólann.

\section{Meira sjálfstæði}

Pað sem var hvað mest áberandi í umræðum í rýnihópum meðal nemenda var að peir töldu sig hafa öðlast aukið sjálfstæði með skólavistinni í NÚ. Gögn úr innra mati skólans sýndu jafnframt að 86\% nemendanna voru sammála um að peir væru orðnir sjálfstæðari eftir skólaárið í NÚ. Pessi orð stúlku í 9. bekk eru lýsandi fyrir pessi viðhorf: „Ég var alls ekki sjálfstæð pegar ég byrjaði í áttunda bekk en núna finnst mér alveg sjálfsagt að geta gert verkefnin sjálf, beisiklí sjá um petta sjálf og bera ábyrgð á pessu sjálf." Pegar nemendur lýstu auknu sjálfstæði lýstu peir aukinni hæfni sinni til að ná settum markmiðum í námi. Samkvæmt fræðunum eru peir pannig að lýsa aukinni hæfni sinni til sjálfstjórnar sem er einmitt eitt meginatriði sjálfsákvörðunarkenninga. Rannsóknir á grunni peirra hafa einmitt sýnt að unglingum sem fá meiri stuðning við sjálfræði (og aðrar sálfræðilegar parfir) gengur betur en öðrum að takast á við breytingar unglingsáranna og að innri sjálfstjórn peirra verður meiri (Grolnick, Gurland, Jacob og Decourcey, 2002; Grolnick, Kurowski og Gurland, 1999; Ryan og Deci, 2017, 2020).

Nemendur voru í framhaldi spurðir hvernig peir teldu að starfshættir í NÚ hefðu gert pá sjálfstæðari. Peir lýstu pví pá hvernig peir hefðu lært að bera ábyrgð á námi sínu með pví að fá frelsi sem skólinn veitti innan tiltekinna ramma. Nemendum eru sett fyrir verkefni (inni á Google classroom) í upphafi hverrar priggja vikna lotu. Í lok lotanna á jafnframt tilteknum verkefnum að vera lokið, eins og áður kom fram. Petta fyrirkomulag töldu nemendur vera lykilatriði í að efla sjálfstjórn peirra. „Maður lærir bara að vera sjálfstæður af pví að maður parf að hafa ábyrgð í náminu," sagði strákur í 10. bekk. Umræður elsta hópsins sýna petta enn frekar:

N1: Petta er eiginlega soldið sett upp pannig að pú getur gert petta á pínum tíma.

N2: Pað eru samt alveg skiladagar fyrir petta, sko.

N3: Maður parf sko alveg að hafa ábyrgð ... Og ef maður gerir ekki pað sem maður parf að gera pá fær maður bara samviskubit í staðinn fyrir að vera skammaður.

N4: Petta er í raun bara eins og undirbúningur fyrir framhaldsskóla. Pað er ekki undirbúið jafn mikið fyrir framhaldsskóla í venjulegum skólum að mínu mati.

Nemendur lýstu pannig fengnu sjálfstæði í samhengi við pað að fá frelsi til að bera ábyrgð á námi sínu. Frelsið felst ekki síst í að nemendur geta unnið verkefni á sínum hraða innan námslotunnar og borið ábyrgð á að skila peim fyrir lotulok. Einnig skal árétta að nemendur höfðu iðulega ýmiss konar val um verkefnin eins og áður var greint frá. Petta er í samræmi við skrif Guðmundar Heiðars Frímannssonar (2010) um samhengi frelsis og ábyrgðar í skólastarfi. Hann bendir á að nemendur geti ekki lært að bera ábyrgð á námi sínu nema peir hafi frelsi til að taka ákvarðanir um pað. Í ljósi pessa er einnig áhugavert að skoða niðurstöður Skólapúlsins hjá NÚ. Pær sýna einmitt að agi í tímum og virk 
pátttaka nemenda í tímum mældist meiri í NÚ en öđrum skólum sem taka pátt í Skólapúlsinum (agi í tímum 1,3*, virk pátttaka nemenda í tímum $0,8^{*}$ ). Jafnframt sýnir Skólapúlsinn að nemendur NÚ telja sig hafa heldur meiri stjórn $\left(0,5^{*}\right)$ en nemendur í í öðrum skólum sem svara Skólapúlsinum, pó munurinn teljist ekki mikill. Pessar niðurstöður, sem lýsa bæði meira frelsi nemenda en einnig meiri aga og virkni, eru ekki síst áhugaverðar í ljósi rannsókna sem sýna að kennarar eru gjarnan hikandi við að veita nemendum frelsi pví peir óttast að missa stjórn, að fái nemendur að taka ákvarðanir um nám sitt hljóti pað að hafa í för með sér einhvers konar stjórnleysi (Ingibjörg V. Kaldalóns, 2017). Hér er einnig rétt að árétta samspil sjálfræðis og formgerðar, sem áður hefur verið vikið að, að nemendur öðlast ríkari sjálfstjórn og peim vegnar betur í námi pegar námsskipulagið er skýrt en sjálfræði nemenda er jafnframt stutt (Reeve, 2006; Reeve og Assor, 2011; Reeve o.fl., 2004; Reeve og Halusic, 2009; Sierens o.fl., 2009).

\section{Gaman í skólanum}

Viðtölin við nemendur voru opnuð með spurningu um hvernig væri að vera nemandi í NÚ. Nemendur sem buðu sig fram í viðtölin lýstu einróma mikilli ánægju með veru sína í skólanum. Svarið var iðulega að pað væri „gaman“ í skólanum. Strákur í 8. bekk sagði til dæmis: „Mér finnst alltaf gaman að mæta í skólann og ég er alltaf glaðari ... Ég var með svo mikinn kvíða í gamla skólanum og svo pegar ég kom hingað pá var ég svo velkominn." Könnun úr innra mati skólans sýndi einnig að 91\% nemenda taldi sér líða vel í NÚ. Ánægja nemenda með NÚ byggðist fyrst og fremst á trausti til samnemenda og kennara. Einnig var ánægjan útskýrð með námsfyrirkomulaginu og sjálfstæðinu (sem áđur var lýst), sem og meiri fjölbreytni í námi, námi sem væri jafnframt skipulagt að einhverju leyti út frá áhugasviði peirra. Hér útskýra nemendur í 10. bekk ánægju sína:

R: Hvað er pað eiginlega sem er svona gaman?

N1: Fólkið.

N2: Já, eiginlega bara mjög góður hópur, sko.

N3: Já, eiginlega pad, sko.

N4: Pað eru sko allir bara vinir og svona.

R: Pegar pið talið um hópinn eigið pið pá við nemendur eða starfsfólk eða?

Allir:Já, bæði, já, alveg ...

Yngri nemendurnir voru sama sinnis og lögðu áherslu á að hópurinn væri ein heild, enda skólinn fámennur. Sömu sjónarmið heyrðust í viðtölum við starfsfólk, að fámennur námshópur skapaði einingu í hópnum. Einnig er mikill samgangur og samvinna á milli árganga. „Við blöndumst ógeðslega vel, ég er til dæmis alltaf með tíunda bekk líka," sagði stelpa í 9. bekk. Í öllum hópunum var jafnframt sagt frá priggja daga óvissuferð sem er farin að hausti á ári hverju og er til pess fallin að vinna með hópefli og styrkja böndin:

Við förum alltaf í byrjun skólaársins í óvissuferð og pá neyðumst við til pess að kynnast öllum og pú veist pá ... allir að kynnast nýju krökkunum sem voru að koma inn. Allir „ég heiti Erla, gaman að kynnast pér" og pannig. Við reynum að blandast og svona smátt og smátt lærir maður öll nöfnin og alls konar pannig.

Pannig er áhersla lögð á að efla félagsfærni og að nemendur upplifi öryggi í hópnum, eins og áđur kom fram. „Við lærum að gera mistök í pessum skóla, við erum að pora að gera mistök,“ sagði strákur í 10. bekk. Pessar áherslur skila sér jafnframt í að nemendur virðast bera mikið traust til kennara skólans og líta á pá sem vini sína. „[Kennararnir] eru eiginlega bara svona vinir okkar ... petta eru miklu skemmtilegri kennarar.“ Strákur í 10. bekk sagði jafnframt: „Peir [kennararnir] skilja okkur.“ Samband nemenda við kennara mældist að sama skapi sterkt í Skólapúlsinum $\left(0,9^{*}\right)$. Pannig er traust milli kennara og nemenda samofið sjálfræðinu eins og áður kom fram (Hafdís Ingvarsdóttir, 2018). Sé litið til fyrri rannsókna á stuðningi við sjálfræði og ánægju í námi kemur petta ekki á 
óvart. Rannsóknir hafa lýst hvetjandi samskiptum í skólastarfi sem mikilvægum pætti í að styðja sjálfræði nemenda. Til dæmis beri kennara sem styður sjálfræði að hlusta eftir hugsunum nemenda, tilfinningum og ákvörðunum og styðja pannig hæfni peirra til sjálfráðra ákvarðana (Roth og Deci, 2009, bls. 78; Reeve og Assor, 2011, bls. 119-120). Hann parf einnig að huga að pví að raddblær sé hvetjandi og uppbyggilegur pannig að nemendur upplifi að námsumhverfið sé styðjandi fremur en stýrandi (Koestner o.fl., 1984).

Nemendur útskýrðu ánægju sína í NÚ einnig út frá ólíku námsfyrirkomulagi, eins og áður var greint frá, og sjálfstæði sem peir öðluðust í gegnum námið. Verkefnin væru jafnframt fjölbreyttari en áður og pví skemmtilegri. Stúlka í 9. bekk lýsir pessu hér:

N: Mér finnst petta ótrúlega fölbreytt, pú veist, allt allt öðruvísi og mér finnst einhvern veginn alltaf gaman að mæta í skólann.

R: En hvað meinarðu með fjölbreytni?

$\mathrm{N}$ : Æ, við erum ekki alltaf bara að læra í bók, pú veist (hinir taka undir). Pegar ég mætti í íslensku í gamla skólanum mínum pá var bara alltaf ein bók og við áttum að gera verkefni úr henni (jáhh hinir taka undir). Maður var kominn með dáldið mikið leið á pví sko.

Ánægja með námið og skólaveruna í NÚ tengist síðast en ekki síst pví að námið er að miklu leyti skipulagt í gegnum áhugasvið nemendanna. Nemendur upplifa pví að nám peirra hafi skýran tilgang, eins og kemur fram í næsta kafla.

\section{Nám sem hefur tilgang}

Pað sem gerði nemendur ekki síst ánægða með skólavistina var að peim fannst áhugamálum sínum frekar mætt í NÚ en öðrum skólum sem peir höfðu reynslu af. Peir nefndu verkefni sem tengdust „ípróttum, næringu og heilsufari“ sem væru áhugaverð. Nemendur töluðu einnig um að kennararnir næðu til peirra par sem peir deildu sama áhugasviði. Petta brot úr samtali nemenda í 10. bekk lýsir pessu:

R: Finnst ykkur að áhugamálunum ykkar sé mætt î pessum skóla?

N1: Klárlega.

N2 og N3: Já, alveg mjög mikið.

N4: Já, algjörlega.

R: Og hvað, getið pið útskýrt fyrir mér hvernig eða með hvaða hætti pað er? Á hvaða hátt?

N3: Sko, kennararnir, peir eru náttúrulega svona íprótta ...

N1: Voru í ípróttum hérna ádur.

N3: Pannig að peir eru með fullt af ráðum, eins og Kristófer.

N1: Peir skilja okkur, sko.

N4: Já Kristófer er búinn að kenna mér fullt af hlutum sem ég hef nýtt mér bæði á æfingum og í keppni.

N3: Pað eru líka bara tímar par sem verið er að vinna með og fræða um líkamann.

N1: Fyrir fólk sem er svona gott í ípróttum og er mikið að bæta sig í ípróttum, pá er verið að færa pað líka yfir í kennsluna, sama áhugamál.

Samtalsbrotið sýnir einnig hvernig nám sem pykir áhugavert verður að sama skapi merkingarbært fyrir nemendum. Pað er í samræmi við skýringar nemenda í fyrri rannsóknum par sem fram kom að nám sem hefur tilgang í augum nemenda er pað sem tengist áhuga peirra, nám sem peim finnst skemmtilegt og, síðast en ekki síst, pað sem peir sjá að geti undirbúið pá fyrir framtíðina (Ingibjörg V. Kaldalóns, 2015). Í rannsóknum sem hafa beinst að sjálfræði og mikilvægi pess að nemendur upplifi að skólaverkefni séu merkingarbær kemur jafnframt fram að hafi nemendur áhuga á verkefninu er 
áhuginn sem slíkur nægur tilgangur í sjálfu sér (Reeve, 2006). Sé áhuginn hins vegar ekki fyrir hendi sé mikilvægt að útskýra gildi og pýðingu verkefna. Pannig sé nemendum veitt tækifæri til að tengja námið við eigin gildi og tilgang og pað geti stuðlað að aukinni sjálfráðri sjálfstjórn (Reeve, 2006).

Ekki aðeins námsefnið sjálft eða tiltekin verkefni höfðu pýðingu fyrir nemendur. Pað var ekki síður pað sem nemendur höfðu lært um persónulegan vöxt sem peim fannst skipta máli. Eftirfarandi tilvitnanir sýna til dæmis hve mikilvægt nemendur telja að hafa lært um sjálfseflingu, jákvætt hugarfar og núvitund:

Pau [kennararnir] tala um að styrkja sjálfan sig og alltaf að segja tala vel um sjálfan sig. Og út af pví pá ertu að breyta hugarfarinu pínu (stelpa í 9. bekk).

$\cdots$

Já maður beisiklí ræður hvernig maður lítur á hlutina eins og pað er búið að kenna okkur mjög mikið. Раð hjálpaði mér allavega mjög mikið pví ég var oft alveg ofboðslega neikvæð (stelpa í 9. bekk).

$\cdots$

Já ég hef ... lært fullt af hlutum sem ég hef notað. Ég hef notað núveruna í keppni til dæmis og á æfingu pegar maður er stressaður eða bara smá stressaður, sko. Ég get klárlega notað petta (strákur í 10. bekk).

Pá sögðu nemendur að markpjálfasamtölin sem peir sækja í skólanum væru „gagnleg“. Pegar innt var eftir hvernig samtölin hjálpuðu peim, pá sögðu nemendur að pau hjálpuðu peim með að vinna að markmiðum sínum. Stúlka í 9. bekk lýsti gagninu af peim með pessum orðum: „Maður er beisiklí að hjálpa sjálfum sér með pví að segja henni [markpjálfanum] hvað mann langar að gera.“

Раð að nemendur upplifi tilgang með námi sínu, ekki síst peim pætti sem snýr að persónulegum vexti peirra, er áhugavert í ljósi rannsóknar í íslenskum skólum sem sýnir að nemendum verður tíðrætt um tilgangsleysi náms pegar peir eru spurðir um málefni skólans (Ingibjörg V. Kaldalóns, 2015). Í nýlegri meistararitgerð sem beindi meðal annars sjónum að viðhorfum nemenda í 10. bekk til lífsleiknikennslu (sem meðal annars snýr að persónulegum vexti nemenda) kom einnig fram að áhöld væru um hvort slík kennsla væri yfirhöfuð gagnleg (Elín Svavarsdóttir, 2017). Par lituðust viðhorf nemenda af peim rótgrónu samfélagslegu hugmyndum um að nám snúist fyrst og fremst um fræðslu um tilteknar námsgreinar, fremur en vöxt einstaklingsins. Pegar íslenskir menntunarfræðingar hafa fjallað um pessar rótgrónu hugmyndir um nám pá lýsa peir gjarnan skólanum sem pekkingarsamfélagi fremur en lærdómssamfélagi. Í pekkingarsamfélagi ráði fræðslan ferðinni og pví er sé lítið rými fyrir einstaklinginn eða eflingu nemenda (sjá til dæmis Hafpór Guðjónsson, 2010 og Ólaf Pál Jónsson, 2013). Pannig mátti sjá hvernig áherslur NÚ á persónulegan vöxt nemenda og mannkostamenntun endurspegluðust í jákvæðum viðhorfum nemenda til pessara pátta námsins.

\section{Samantekt og lokaord}

Pað sem stóð upp úr, eftir að hafa verið á vettvangi hjá NÚ, var ánægja nemenda með skólastarfið og talar titill greinarinnar sínu máli. Námsskipulagið og pað andrúmsloft sem skapast hefur í NÚ stuðlar að ánægju meðal nemenda og peir finna tilgang með námi sínu við skólann. Peir hafa jafnframt proskað með sér meiri sjálfstjórn og hæfni til að bera ábyrgð á námi sínu, að eigin mati. Prátt fyrir að fræðimenn hafi fjallað um frelsi nemenda og sjálfræði í áratugi sýna íslenskar rannsóknir að stuðningur við sjálfræði nemenda í íslenskum grunnskólum er víðast hvar ekki mikill. Pá hefur komið fram að víða telja kennarar sig skorta hugmyndir um skipulag fyrir nám sem veitir nemendum frelsi til að taka ákvarðanir og bera ábyrgð á námi sínu. Pví er áhugavert að líta til starfshátta NÚ og ekki síst til pess námsskipulags sem par hefur verið próað. Par vekur til dæmis athygli hvatakerfi sem 
umbunar með auknu frelsi og sjálfstæði nemenda. Pá grundvallast skipulagið ekki síst á vendinámi, leiðsagnarmati og upplýsingatækni sem heldur utan um nám og verkefnaskil hvers nemanda. Síðast en ekki síst er áhersla lögð á áhugadrifið nám, val nemenda og sjálfsábyrgð sem styður sjálfræði beirra. Pá vakti orðræða kennaranna athygli rannsakanda, en hún endurspeglar pær hefðir og hugmyndir sem stýra starfsháttum (Bernstein, 2000). Í NÚ snerist orðræðan um sjálfseflingu nemenda og að skapa öruggt skólaumhverfi fyrir vöxt hvers einstaklings sem manneskju, fremur en um fræðslu um tilteknar námsgreinar. Að verða meiri manneskjur, eða öllu heldur að verða „meira maður“ eins og Páll Skúlason (1987) orðaði pað. Í peim anda er við hæfi að enda pessa grein með orðum hins krítíska uppeldisfræðings Paulo Freire um gildi sjálfræðis í skólastarfi: „Enginn er fyrst sjálfráða og tekur svo ákvörðun. Sjálfræði er útkoma ferlis par sem tekinn er fjöldi ólíkra ákvarðana ... Sjálfræði er ferli sem felur í sér að verða maður sjálfur, ferli sem felur í sér proska, að læra að vera til“" (2001, bls. 98, pýðing höfundar) ${ }^{1}$.

\section{"I'm always happier now and I'm much more independent than I was before" Autonomy support in practice - A look at an Icelandic compulsory school}

The purpose of this paper is to shed light on practices that support student autonomy, and examine the students' experiences with these practices. The paper examines a case study conducted in the compulsory school NOW, where autonomy support figures as one of the school's stated goals. Despite the fact that scholars have discussed notions concerning student freedom and autonomy for decades, both Icelandic and international studies show that support for student autonomy is widely insufficient. It has also been revealed that many teachers claim they lack ideas on how to structure their teaching in ways that offer students the freedom to make decisions regarding their own learning and take responsibility for their education. It would, therefore, be beneficial to Icelandic schools to strengthen the understanding of practices that support student autonomy, and no less, to shed light on students' experience of these practices, as is the aim of the current paper.

NOW is an independently run compulsory school for students in grades 8-10. The school was founded four years ago, in 2016. Around 60 students attend the school. The school is particularly aimed at students with a background in sports, although there are no explicit requirements for athletic achievement. In addition to autonomy support, the school seeks to facilitate each student's interests, health and wellbeing. Autonomy support refers to conditions created and measures taken in schools (structure, atmosphere, space) that support students' autonomy. The school attracted the researcher's attention because it is one of few schools in the world that upholds self-determination theories as one of its major professional aims. Self-determination is considered as the foundation to self-regulation, motivation and wellbeing. Self-determination theories have contributed significantly to the understanding of these key aspects of education. The paper will analyze a case study, conducted between 2018 and 2019, focusing on students in grades 8-10 in an Icelandic compulsory school. A seven-day field study was carried out in the spring of 2018, as well as during five school days in spring 2019. Three focus group interviews were held, involving 12 students, and eight personal interviews with five members of staff. The study also made use of data concerning the school's self evaluation.

The school practices in NOW turned out to be quite different from what is generally the case in Icelandic studies on the matter. Structures that specifically support student autonomy are continuously developing. For example, a certain incentive system was designed that rewards students for good conduct and for handing in assignments on time. As a result, students were awarded more freedom than is generally practiced and they were also expected to take more responsibility for their studies. Flipped learning, formative evaluation and IT also played an important part in overseeing each student's

\footnotetext{
No one is first autonomous and then makes a decision. Autonomy is a result of a process involving various and innumerable decisions ... Autonomy is a process af becoming oneself, a process of maturing, of coming to be.
} 
learning. Moreover, emphasis on students' personal growth and social skills was woven into all aspects of the school work, for instance through mindfulness lessons, coaching and mindset training. The school's discourse orbits around the student's empowerment in conjunction with creating a safe environment for the growth of each individual as a human being, rather than education based on instruction in a given subject.

The students' experience of the schooling was positive. Even though the students were offered more space and freedom to choose, their self-discipline was more salient than the norm. In this way, the students had grown to acquire more self-regulation and skill to take responsibility for their own learning, describing themselves as independent learners. The students enjoyed their school day and described a positive school atmosphere, not least due to the positive nature of their relationships with teachers and their peers. What also influenced contentment with the school work was the fact that the students felt that their interests were met to a stronger extent in NOW than in other schools they had attended. Most important in this context was the teachers' ability to relate to students who shared their field of interest. In this sense, the students felt a sense of purpose to their learning at the school. Furthermore, the students found the school's emphasis on personal growth and social skills to be both practical and useful.

The study is telling in terms of how academic studies can prove useful for school practices. There are many things that can be learned from a school that actively develops a curriculum aimed at facilitating the growth and autonomy of students. Such practices yield contented students who are also capable of taking responsibility for their learning.

Key words: Autonomy support, self-determination theories, school-practices, students' experience

\section{Um höfund}

Ingibjörg Kaldalóns (ingakald@hi.is) er lektor við Menntavísindasvið Háskóla Íslands. Hún lauk BA-prófi i stjórnmála- og félagsfræði frá Félagsvísindadeild Háskóla Íslands árið 1993, MA-gráðu í félagsfræði frá sömu deild 1996 og doktorsprófi frá Menntavísindasviði Háskóla Íslands árið 2015. Í rannsóknum sínum hefur Ingibjörg einkum beint sjónum að starfsháttum í grunnskólum, pátttöku, sjálfræði og prautseigju nemenda í skólastarfi sem og velfarnaði nemenda og kennara.

\section{About the author}

Ingibjörg Kaldalóns (ingakald@hi.is) is an assistant professor at the School of Education, University of Iceland. She acquired a BA degree in political science 1993 from the Faculty of Social Science at University of Iceland and MA degree in Sociology 1996 from the same Faculty. She has a PhD degree in Education since 2015, from the School of Education, University of Iceland. Her research is in the field of school practices that support teachers' and students' empowerment, resilience and well-being. 


\section{Heimildir}

Admiraal, W., Nieuwenhuis, G., Kooij, Y., Dijkstra, T. og Cloosterman, I. (2019). Perceived autonomy support in primary education in the Netherlands: Differences between teachers and their students. World Journal of Education, 9(4), 1-12. doi:10.5430/wje.v9n4p1

Assor, A. og Kaplan, H. (2001). Mapping the domain of autonomy support. Í A. Efklides (ritstjóri), Trends and prospects in motivation research (bls. 101-120). Kluwer, Hollandi: Kluwer Academic Publishers.

Assor, A., Kaplan, H. og Roth, G. (2002). Choice is good but relevance is excellent: Autonomy-enhancing and suppressing teacher behaviours predicting students' engagement in schoolwork. British Journal of Educational Psychology, 72(2), 261-278.

Bandura, A. (2008). Toward an agentic theory of the self. Í H. W. Marsh, R. G. Craven og D. M. McInerney (ritstjórar), Self-processes, learning, and enabling human potential (bls. 15-49). Charlotte, NC: Information Age Publishing.

Bernstein, B. (2000). Pedagogy, symbolic control and identity. Theory, research, critique. Lanham: Rowman og Littlefield Publishers.

Cleary, T. J. og Zimmerman, B. J. (2004). Self-regulation empowerment program: A school-based program to enhance self-regulation and self-motivated cycles of student learning. Psychology in the Schools, 41(5), 537-550. doi:10.1002/pits. 10177

Elín Svavarsóttir. (2017). „Lifið er leikur, ertu far um að taka pátt i pvi?" Lifsleikni á unglingastigi, viðhorf kennara og nemenda til lifsleiknikennslu (óútgefin M.Ed.-ritgerð). Háskóli Íslands, Reykjavík.

Freire, P. (2001). Pedagogy of freedom. Ethics, democracy and civic courage. New York: Lowman og Littlefield publishers.

Gerður G. Óskarsdóttir. (2012). Skil skólastiga: Frá leikskóla til grunnskóla og grunnskóla til framhaldsskóla. Reykjavík: Háskólaútgáfan og Skóla- og frístundasvið Reykjavíkurborgar.

Glasser, W. (1988). Choice theory in the classroom (2. útgáfa). New York: Harper Perennial.

Grolnick, W. S., Gurland, S. T., Jacob, K. F. og Decourcey, W. (2002). The development of self-determination in middle childhood and adolescence. I A. Wigfield og J. S. Eccles (ritstjórar), Development of achievement motivation (bls. 147-171). New York: Academic Press.

Grolnick, W. S., Kurowski, C. O. og Gurland, S. T. (1999). Family processes and the development of children's self-regulation. Educational Psychologist, 34(1), 3-14.

Guðmundur Heiðar Frímannsson. (2010). Sjálfræði, gott líf og uppeldi. Í Salvör Nordal, Sigrún Júlíusdóttir og Vilhjálmur Árnason (ritstjórar), Velferð barna, gildismat og ábyrgð samfélagsins (bls. 31-43). Reykjavík: Siðfræðistofnun og Háskólaútgáfan.

Guðrún Alda Harðardóttir og Baldur Kristjánsson. (2012). Viðhorf tveggja leikskólakennara og aðferðir við valdeflingu leikskólabarna. Tímarit um menntarannsóknir, 9(1), 112-131.

Hafdís Ingvarsdóttir. (2018). Kennsluhættir speglaðir í ljósi sjálfræðis: Virðing, ábyrgð og traust. Sérrit Netlu 2018 - Framhaldsskólinn i brennidepli. Sótt af http://netla.hi.is/serrit/2018/framhaldskolinn_brennidepli/03.pdf

Hafpór Guðjónsson. (2010). Að vitsmunir barnanna proskist í náminu. Netla. Sótt af http://netla.hi.is/greinar /2010/010/index.htm

Ingibjörg V. Kaldalóns. (2015). Stuðningur við sjálfreði nemenda i islenskum grunnskólum (óútgefin doktorsritgerð). Háskóli Íslands, Reykjavík.

Ingibjörg V. Kaldalóns. (2017). Hvað hindrar kennara við að styðja sjálfræði nemenda í skólastarfi? Netla Veftimarit um uppeldi og menntun. Sótt af https:/opinvisindi.is/bitstream/handle/20.500.11815/592/004. pdf? sequence $=1$ \& is Allowed $=y$

Jang, H., Reeve, J. og Deci, E. L. (2010). Engaging students in learning activities: It's not autonomy support or structure, but autonomy support and structure. Journal of Educational Psychology, 102(3), 588-600. doi: $10.1037 / \mathrm{a} 0019682$

Jang, H., Reeve, J. og Halusic, M. (2016). A new autonomy-supportive way of teaching that increases conceptual learning: Teaching in students' preferred ways. The Journal of Experimental Education, 84(4), 686-701. doi: 10.1080/00220973.2015.1083522 
Jóhanna Einarsdóttir. (2008). Við megum ráða pegar við erum búin með bækurnar. Reynsla barna í 1. bekk grunnskóla. Uppeldi og menntun, 17(2), 9-30.

Kaplan, H. og Assor, A. (2012). Enhancing autonomy-supportive I-thou dialogue in schools: Conceptualization and socio-emotional effects of an intervention program. Social Psychology of Education, 15(2), 251-269. doi: 10.1007/s1 1218-012-9178-2

Koestner, R., Ryan, M. R., Bernieri, F. og Holt, K. (1984). Setting limits on children's behavior: The differential effects of controlling vs. informational styles on intrinsic motivation and creativity. Journal of Personality, 52(3), 233-248.

Kristján Ketill Stefánsson. (2017). School engagement and intentional self-regulation: A reciprocal relation in adolescence (óútgefin doktorsritgerð). Háskóli Íslands, Reykjavík.

Lichtman, M. (2013). Qualitative research in education. A user's guide (3. útgáfa). Los Angeles: Sage.

Mennta- og menningarmálaráðuneyti. (2011). Aðalnámskrá grunnskóla: Almennur hluti 2011. Reykjavík: Höfundur.

Núnez, J. L. og León, J. (2019). Determinants of classroom engagement: A prospective test based on selfdetermination theory. Teachers and teaching, 25(2), 147-159. doi:10.1080/13540602.2018.1542297

Ólafur Páll Jónsson. (2013). Lyłðræði. Hvað geta skólar gert? [fyrirlestur á alpjóðlegum degi heimspekinnar, 21. nóvember 2013].

Patall, E. A. og Zambrano, J. (2019). Facilitating student outcomes by supporting autonomy: Implications for practice and policy. Policy Insights from the Behavioral and Brain Sciences, 6(2), 115-122. doi: $10.1177 / 2372732219862572$

Páll Skúlason. (1987). Viðhorf til menntunar. Í Páll Skúlason, Pelingar (bls. 299-308). Reykjavík: Ergo.

Reeve, J. (2006). Teachers as facilitators: What autonomy-supportive teachers do and why their students benefit. The Elementary School Journal, 106(3), 225-237. doi:10.1037/0022-0663.98.1.209

Reeve, J. (2009). Why teachers adopt a controlling motivating style toward students and how they can become more autonomy supportive. Educational Psychologist, 44(3), 159-175. doi:10.1080/00461520903028990

Reeve, J. og Assor, A. (2011). Do social institutions necessarily suppress individuals' need for autonomy? The possibility of schools as autonomy-promoting contexts across the globe. Í V. I. Chirkov, R. M. Ryan og K. M. Sheldon (ritstjórar), Human autonomy in cross-cultural context: Perspectives on psychology of agency, freedom, and well-being (bls. 111-132). New York: Springer.

Reeve, J., Deci, E. L. og Ryan, R. M. (2004). Self-determination theory: A dialectical framework for understanding sociocultural influences in student motivation. Í D. M. McInerney og S. V. Etten (ritstjórar), Research on sociocultural influences on motivation and learning: Big theories revisited (bls. 31-59). Greenwich, CT: Information Age Publishing.

Reeve, J. og Halusic, M. (2009). How K-12 teachers can put self-determination theory principles into practice. Theory and Research in Education, 7(2), 145-154. doi:10.1177/1477878509104319

Reeve, J., Ryan, R. M., Deci, E. L. og Jang, H. (2008). Understanding and promoting autonomous self-regulation: A self-determination theory perspective. Í D. Schunk og B. Zimmerman (ritstjórar), Motivation and self-regulated learning: Theory, research, and application (bls. 223-244). New York: Francis Group.

Reykjavíkurborg, Skóla- og frístundasvið. (2018). Menntastefna til 2030 - látum draumana retast. Sótt af https:// reykjavik.is/sites/default/files/Almennt_efni/menntastefna_rvk_20x20-lores22.02.pdf

Roth, G. og Deci, E. L. (2009). Autonomy. Í S. J. Lopez (ritstjóri), The encyclopedia of positive psychology (bls. 78-82). West-Sussex: Wiley-Blackwell.

Rúnar Sigpórsson. (2012). „en pað, náttúrulega, mætti vera meira um rökhugsun og tjáningu“: Námsmenning á unglingastigi grunnskóla og áhrif hennar á próun námshæfni nemenda. Gleður, 22, 88-98.

Rúnar Sigpórsson, Anna-Lind Pétursdóttir og Póra Björk Jónsdóttir. (2014). Nám, pátttaka og samskipti nemenda. Í Gerður G. Óskarsdóttir (ritstjóri), Starfshattir i grunnskólum við upphaf21. aldar (bls. 161-196). Reykjavík: Háskólaútgáfan.

Ryan, R. M., Curren, R. og Deci, E. L. (2013). What humans need: Flourishing in Aristotelian philosophy and self-determination theory. I A. S. Waterman (ritstjóri), The best within us: Positive psychology perspectives on eudaimonia (bls. 57-75). Washington, DC: American Psychological Association. 
Ryan, R. M. og Deci, E. L. (2017). Self-determination theory. Basic psychological needs in motivation, development and wellness. New York: The Guilford Press.

Ryan, R. M. og Deci, E. L. (2020). Intrinsic and extrinsic motivation from a self-determination theory of perspective: Definitions, theory, practices, and future directions. Contemporary Educational Psychology. doi: 10.1016/j.cedpsych.2020.101860

Ryan, R., Huta, V. og Deci, E. L. (2008). Living well: A self-determination theory perspective on eudaimonia. Journal of Happiness Studies, 9(1), 139-170. doi:10.1007/s10902-006-9023-4

Sheldon, K. M. og Ryan, R. M. (2011). Positive psychology and self-determination theory: A natural interface. Í V. I. Chirkov, R. M. Ryan og K. M. Sheldon (ritstjórar), Human autonomy in cultural contexts. Perspectives on the psychology of agency, freedom and well-being (bls. 33-44). New York: Springer.

Sierens, E., Vansteenkiste, M., Goossens, L., Soenens, B. og Dochy, F. (2009). The synergistic relationship of perceived autonomy support and structure in the prediction of self-regulated learning. British Journal of Educational Psychology, 79, 57-68. doi:10.1348/000709908X304398

Skólapúlsinn. (2018). Nemendakönnun 6.-10. b. 2017-2018. Grunnskólinn NÚ [skýrsla um niðurstöður nemendakönnunar hjá NÚ]. Egilsstaðir: Vísar - rannsóknir.

Stefanou, C. R., Perencevich, K. C., DiCintio, M. og Turner, J. C. (2004). Supporting autonomy in the classroom: Ways teachers encourage student decision making and ownership. Educational Psychologist, 39(2), 97-110. doi:10.1207/s15326985ep3902_2

Steinunn Gestsdóttir og Freyja Birgisdóttir. (2010). Sjálfstjórn. Forsenda farsældar á fyrstu skólaárunum. Rádstefnurit Netlu - Menntakvika 2010. Sótt af http://netla.hi.is/menntakvika2010/alm/027.pdf

Steinunn Gestsdóttir og Lerner, R. M. (2007). Hlutverk sjálfstjórnar í æskilegum proska barna og unglinga. Sálfræðiritið - Tímarit Sálfreðingafélags Íslands, 12, 37-55.

$\mathrm{Su}$, Y. og Reeve, J. (2011). A meta-analysis of the effectiveness of intervention programs designed to support autonomy. Educational Psychology Review, 23, 159-188. doi: 10.1007/s10648-010-9142-7

Yu, C., Li, X., Want, S. og Zhang, W. (2016). Teacher autonomy support reduces adolescent anxiety and depression: An 18-month longitudinal study. Journal of Adolescence, 49, 115-123. doi:10.1016/j.adolescence.2016.03.001

Ingibjörg V. Kaldalóns. (2020).

„Ég er alltaf glaðari og ég er miklu sjálfstæðari en ég var“ Starfshættir í grunnskóla sem styður sjálfræði nemenda

Netla - Veftímarit um uppeldi og menntun: Sérrit 2020 - Menntavika 2020.

Sótt af http://netla.hi.is/serrit/2020/menntavika_2020/06.pdf

DOI: https://doi.org/10.24270/serritnetla.2020.12 